\title{
PENGARUH STRES KERJA, KEPUASAN KERJA DAN DUKUNGAN SOSIAL TERHADAP KINERJA PERAWAT DI PUSKESMAS SEBATIK
}

\author{
THE EFFECT OF WORK STRESS, WORK SATISFACTION AND SOCIAL \\ SUPPORT TO NURSING PERFORMANCE IN SEBATIK'S COMMUNITY \\ HEALTH CENTRE (PUSKESMAS)
}

\author{
Meylin Rahmawati ${ }^{1)}$ \\ Irwana ${ }^{2)}$ \\ Universitas Borneo Tarakan \\ rahmwatimeylin@gmail.com
}

Abstrak: Penelitian ini bertujuan untuk mengetahui: (1) pengaruh Stres Kerja terhadap kinerja perawat Puskesmas Sebatik, (2) pengaruh Kepuasan Kerja terhadap Kinerja perawat Puskesmas Sebatik dan (3) pengaruh Dukungan Sosial terhadap Kinerja perawat Puskesmas Sebatik. Populasi dalam penelitian ini adalah perawat puskesmas Sungai Nyamuk dan puskesmas Aji Kuning. Teknik Pengambilan sampel dengan menggunakan non probability sampling dengan metode sampling jenuh. Data penelitian berasal dari kuesioner yang di buat dengan skala likert dan dianalisis dengan menggunakan regresi linier berganda.

Hasil ini menunjukkan bahwa Stres kerja berpengaruh negatif dan signifikan terhadap Kinerja perawat dengan nilai thitung sebesar 2,991, ttabel sebesar 1,69389 dan nilai signifikan sebesar 0,005, maka dapat di simpulkan bahwa thitung > ttabel dan nilai signifikan lebih kecil dari 0,05. Kepuasan Kerja tidak berpengaruh dan tidak signifikan terhadap Kinerja perawat, dengan nilai thitung sebesar 1,390, ttabel sebesar 1,69389 dan nilai signifikan sebesar 0,174, maka dapat di simpulkan bahwa thitung < ttabel dan nilai signifikan lebih besar dari 0,05. Dukungan Sosial berpengaruh positif dan tidak signifikan terhadap Kinerja perawat, dengan nilai thitung sebesar 1,992, ttabel sebesar 1,69389 dan nilai signifikan sebesar 0,055, maka dapat di simpulkan bahwa thitung > ttabel dan nilai signifikan lebih besar dari 0,05.

Kata Kunci : Stres Kerja, Kepuasan kerja, Dukungan Sosial, Kinerja

Abstract: This study aims to determine: (1) the effect of Job Stress on the nurse performance of Sebatik Health Center, (2) the effect of Job Satisfaction on Puskesmas nurse performance Sebatik and (3) the effect of Social Support on the Performance of nurses at the Sebatik Health Center. The population in this study were nurses from Sungai Nyamuk health center and Aji Kuning health center. Sampling technique using non probability sampling withmethod saturated sampling. The research data comes from questionnaires made with a Likert scale and analyzed using multiple linear regression.

These results indicate that the stress of work a significant negative effect on the nurses performance with value tcount, of 2,991, ttable of 1,69389 and significant value of 0.005, it can be concluded that tcount $>$ ttable and a significant smaller value than 0,05. Job satisfaction has no effect and is not 
significant to the performance of nurses, with a value tcount of 1,390 ttable of 1,69389 and significant value of 0.174, it can be concluded that tcount $<$ ttable and significant value greater than 0.05. Social support and no significant positive effect on the Performance of nurses, with a value tcount of 1,992 ttable of 1,69389 and significant value of 0.055, it can be concluded that tcount > ttable and significant value greater than 0.05 .

Keywords: Job Stress, Job Satisfaction, Social Support, Performance

\section{LATAR BELAKANG}

Puskesmas merupakan fasilitas pelayanan kesehatan yang memiliki peran sangat strategis dalam upaya mempercepat peningkatan derajat kesehatan sebagian masyarakat Indonesia. Perawat Salah satu profesi yang mempunyai peran penting di puskesmas. Perawat merupakan salah satu profesi yang memiliki andil besar dalam menentukan keberhasilan rumah sakit atau puskesmas dalam memberikan pelayanan kesehatan kepada masyarakat, hal ini disebabkan selama 24 jam perawat berperan menghadapi masalah kesehatan pasien secara terusmenerus (Faudin $\mathrm{dkk}, 2015)$. Seorang perawat dituntut untuk selalu profesional dan berkualitas dalam memberikan pelayanan kepada pasien. Semakin meningkatnya tuntutan tugas yang dihadapi perawat, maka dapat meningkatkan stres. Perawat dihadapkan dengan berbagai masalah yang di keluhkan pasien yang bermacam-macam, hubungan dengan rekan kerja dan atasan yang tidak terjalin dengan baik, beban kerja yang berat, di ruang rawat inap yang pekerjaannya kompleks dan monoton, dan ditambah dengan tuntutan tugas yang harus dicapai (Suryaningrum 2015). Dari situasi dan tuntutan kerja perawat bisa membuat perawat stres dan mengganggu pekerjaannya serta dapat menurunkan kinerja perawat Kinerja merupakan hasil pekerjaan yang mempunyai hubungan kuat dengan tujuan strategis organisasi, kepuasan konsumen, dan memberikan kontribusi pada ekonomi (Armstrong dan Baron, 1998:15). Kinerja adalah tentang apa yang dikerjakan dan bagaimana cara mengerjakannya. Seorang karyawan dikatakan berhasil melaksanakan pekerjaannya atau memiliki kinerja yang baik, apabila hasil kerja yang diperoreh lebih tinggi dari standar kinerja. Penilaian kinerja dapat dilakukan dengan membandingkan hasil kerja yang dicapai karyawan dengan standar pekerjaan. Bila hasil kerja yang diperoleh sampai atau melebihi standar pekerjaan dapat dikatakan kinerja seorang karyawan termasuk pada kategori baik. Demikian sebaliknya, seorang karyawan yang hasil pekerjaannya tidak mencapai standar pekerjaan termasuk pada kinerja yang tidak baik atau berkinerja rendah (Bangun 2012). Menurut Wirawan (2009) salah satu faktor yang mempengaruhi kinerja yaitu, stres kerj 
a.

Stres kerja yang dialami perawat dapat mengganggu kinerja dan mengurangi produktivitas perawat dalam memberikan pelayanan kepada pasien. Perawat yang mengalami stres menjadi nervous dan merasakan kekuatiran kronis. Mereka sering menjadi marah-marah, agresif, tidak dapat relaks, atau memperlihatkan sikap yang tidak kooperatif (Hasibuan, 2009). Stres yang dibiarkan begitu saja tanpa penanganan yang serius dari pihak perusahaan membuat karyawan menjadi tertekan, tidak termotivasi, dan frustasi. Pada tahap yang semakin parah, stres bisa membuat karyawan menjadi sakit atau bahkan akan mengundurkan diri. (Gaffar 2012). Selain stres kerja, kinerja juga di pengaruhi oleh kepuasan kerja. (Wirawan, 2009).

Kepuasan kerja merupakan sikap emosional yang menyenangkan dan mencintai pekerjaanya (Hasibuan, 2014). Kepuasan kerja mencerminkan perasaan seseorang terhadap pekerjannya. Ini Nampak dalam sikap positif karyawan terhadap pekerjaan dan segala sesuatu yang dihadapi di lingkungan kerjanya. Dengan perasaan yang positif dan senang berkaitan dengan pekerjaan, karyawan diharapkan bekerja dengan baik untuk mencapai kinerja yang diharapkan begitupun sebaliknya (Admaji, 2011). Selain kepuasan kerja dan stres kerja, kinerja juga dapat di pengaruhi oleh Dukungan Sosial. (Yulia, 2017).

Dukungan sosial merupakan dukungan emosional, mendorong adanya ungkapan perasaan, memberi nasihat atau informasi, serta memberikan bantuan berupa material
(Smet, 1994). Bagi karyawan dukungan sosial sangat diperlukan guna untuk mengurangi stress kerja. Karena, semakin besar dukungan sosial yang diterima maka semakin rendah tingkat stress kerjanya dan begitu juga sebaliknya. Perawat yang dukungan sosialnya rendah akan mengalami kondisi kerja yang kurang nyaman diakibatkan dari hubungan yang kurang harmonis. Dukungan sosial yang rendah akan mempengaruhi tingkat stres kerja seseorang (Suryaningrum, 2015). Dukungan sosial yang dimaksud disini adalah dukungan sosial yang didapat dari lingkungan pekerjaan yaitu seperti rekan kerja dan keluarga maupun teman di luar lingkungan kerja. Sehingga, banyak kasus yang menunjukan bahwa, para karyawan yang mengalami stress kerja adalah mereka yang tidak mendapatkan dukungan dari rekan sekerjanya.

Ada 5 puskesmas yang ada di Sebatik yakni Puskesmas Setabu, Puskesmas Aji Kuning, Puskesmas Lapri, Puskesmas Sungai Nyamuk dan Puskesmas Sungai Taiwan. Di antaranya ada tiga yang membuka layanan rawat inap 24 jam yakni Puskesmas Setabu, Puskesmas Aji Kuning dan Puskesmas Sungai Nyamuk sehingga dilakukannya shift kerja untuk perawat. Shift kerja merupakan salah satu strategi yang dilakukan perusahaan untuk meningkatkan produktivitas secara maksimal dan efisien namun berpotensi menyebabkan stres kerja pada karyawan (Marchelia 2014). Berdasarkan hasil wawancara dari salah satu karyawan di Puskesmas Aji Kuning dan Puskesmas Sungai Nyamuk mengatakan bahwa tenaga Perawat di Puskesmas tersebut 
kurang karena sebagian tenaga Perawat telah pindah tugas di Rumah Sakit Pratama di Tanjung Karang yang telah di resmikan pada awal bulan Agustus 2018 lalu. Adapun puskesmas yang ingin menjadi objek penelitian saya yaitu puskesmas Aji Kuning dan Puskesmas Sungai Nyamuk.

\section{PERUMUSAN MASALAH}

Berdasarkan latar belakang yang dikemukakan, maka rumusan masalah dalam penelitian ini adalah Apakah Stres Kerja,Kepuasan Kerja dan Dukungan Sosial berpengaruh terhadap KInerja Perawat Puskesmas Sebatik

\section{TUJUAN PENELITIAN}

Sesuai dengan permaslahan yang telah dirumuskan, tujuan penelitian adalah sebagai berikut :

1. Untuk mengetahui pengaruh stress kerja terhadap kinerja perawat Puskesmas di Kecamatan Sebatik.

2. Untuk mengetahui pengaruh kepuasan kerja berpengaruh terhadap kinerja perawat Puskesmas di Kecamatan di Sebatik.

3. Untuk mengetahui pengaruh dukungan sosial terhadap kinerja perawat Puskesmas di Kecamatan Sebatik.

\section{TINJAUAN PUSTAKA}

\section{$\underline{\text { Stres Kerja }}$}

\begin{tabular}{|c|c|}
\hline Stres & kerja adalah \\
\hline $\begin{array}{l}\text { ondisi } \\
\text { enciptakan }\end{array}$ & ketegangan \\
\hline
\end{tabular}

ketidakseimbangan fisik dan psikis, yang mempengaruhi emosi, proses berpikir, dan kondisi seorang keryawan (Siagian, 2018). Dengan adanya stres kerja yang tinggi akan menurunkan kinerja perawat (Gaffar 2012).

Dampak Stres Stress menunjukkan gejala-gejalanya dalam sejumlah cara. Misalnya, seseorang yang sedang mengalami stress dengan level yang tinggi dapat berkembang menuju tekanan darah tinggi, luka lambung, iritabilitas, sulit dalam Pengambilan keputusan rutin, kehilangan selera makan, kecenderungan memperoleh kecelakaan dan lain-lain serupa itu. Semua gejala-gejala ini di kelompokkan dalam tiga kategori umum: gejala-gejala fisiologis, psikologis, dan perilaku (Muchlas, 2005). 1. Gejala-gejala Fisiologis Yang terbanyak menjadi perhatian kita tentang stress adalah gejalagejala fisiologis. Hal ini secara menonjol disebabkan oleh kenyataan adanya berbagai topic penelitian yang dilakukan oleh para spesialis dalam ilmu kesehatan dan kedokteran. Penelitian ini berpendapat bahwa stress dapat menciptakan perubahanperubahan dalam metabolism, meningkatkan angka denyut jantung dan pernapasan, menaikkan tekanan darah, menimbulkan sakit kepala, dan merangsang timbulnya serangan jantung. Hubungan antara stress dengan gejala-gejala fisik yang khusus tersebut tidak begitu jelas. Hanya sedikit, kalau ada, yang memiliki hubungan konsisten (Beehr \& Newman, 1978). Hal ini menunjukkan kompleksnya gejalagejala dan kesukaran untuk 
mengukur gejala-gejala tersebut secara objektif.

2. Gejala-gejala Psikologis Stress dapat menyebabkan timbulnya ketidakpuasan. Stress yang berhubungan dengan pekerjaan dengan sendirinya dapat menyebabkan ketidakpuasan kerja. Ketidakpuasan kerja, dalam kenyataannya adalah efek psikologi dari stress yang paling sederhana dan jelas. Tetapi stress menunjukkan dirinya dalam status psikologis tertentu, misalnya ketegangan, kecemasan, ketrsinggungan, kebosanan, dan keras kepala. Bukti menunjukkan bahwa ketika orang ditempatkan dalam pekerjaanpekerjaan yang membuat banyak tuntutan yang mengandung konflik atau dalam pekerjaan yang kurang jelas tentang kewajibankewajiban, kewenangan dan tanggung jawab karyawan, maka baik stress maupun ketidakpuasan akan meningkat (Cooper \& Marshall, 1976). Demikian pula, makin sedikit orangorang memiliki control terhadap waktu kerja mereka, makin besar pula stress dan ketidakpuasannya. Meskipun masih diperlukan penelitian-penelitian lagi untuk mengklarifikasi hubungan stress dengan pekerjaan, beberapa bukti telah menyatakan bahwa pekerjaanpekerjaan yang hanya memberikan tingkat variasi, signifikansi, autonomi, umpan-balik dan identitas yang rendah untuk para karyawan, akan menciptakan stress dan mengurangi kepuasan dan keterlibatan dalam pekerjaan (Hackman \& Oldham, 1975).

3. Gejala-gejala Perilaku Gejalagejala stress yang berhubungan dengan perilaku termasuk perubahan-perubahan dalam produktivitas, absensi, dan pindah kerja, juga perubahan-perubahan dalam kebiasaan makan, lebih sering merokok dan bertambahnya minum alcohol, bicara menjadi cepat, bertambahnya gelisah, dan adanya gangguan tidur

\section{$\underline{\text { Kepuasan Kerja }}$}

Kepuasan kerja mencerminkan perasaan seseorang terhadap pekerjannya. Ini Nampak dalam sikap positif karyawan terhadap pekerjaan dan segala sesuatu yang dihadapi di lingkungan kerjanya (Admaji, 2011). kepuasan kerja merupakan sikap emosional yang menyenangkan dan mencintai pekerjaanya (Hasibuan, 2014). Dengan adanya kepuasan kerja bisa meningkatkan kinerja perawat (Admaji, 2011).

Kepuasan keja pada dasarnya merupakan sesuatu yang bersifat individual. setiap individu memiliki tingkat kepuasan yang berbeda-beda sesuai dengan sistem nilai yang berlaku pada dirinya, semakin tinggi penilaian terhadap kegiatan dirasakan sesuai dengan keinginan individu, maka semakin tinggi kepuasannya terhadap kegiatan tersebut. Dengan demikian, kepuasan merupakan evaluasi yang menggambarkan seseorang atas perasaan sikapnya senang atau tidak senang, puas atau tidak puas dalam bekerja (Rivai, 2004).

$\underline{\text { Dukungan Sosial }}$

Dukungan sosial merupakan dukungan emosional, mendorong adanya ungkapan perasaan, memberi 
nasihat atau informasi, serta memberikan bantuan berupa material (Smet, 1994). Dengan adanya dukungan sosial yang tinggi maka akan meningkatkan kinerja perawat (Yulia, 2017).

$\underline{\text { Kinerja }}$

Manajemen kerja adalah
manajemen tentang menciptakan
hubungan dan memastikan
komuniksi yang efektif. Manajemen
kinerja memfokuskan pada apa yang
diperlukan oleh organisasi, manajer,
dan pekerja untuk berhasil.
Manajemen kinerja adalah tentang bagaimana kinerja dikelolah untuk memperoleh sukses (Wibowo, 2013). Kinerja berasal dari pengertian perfomence. Ada pula yang memberikan pengertian performance sebagai hasil kerja atau prestasi kerja. Namun, sebenarnya kinerja mempunyai makna yang lebih luas, bukan hanya hasil kerja, tetapi termasuk bagaimana proses pekerjaan berlangsung. Bangun (2012) menyatakan kinerja (performance) adalah hasil pekerjaan yang dicapai seseorang berdasarkan persyaratan-persyaratan pekerjaan (job performance). Kinerja merupakan hasil pekerjaan yang mempunyai hubungan kuat dengan tujuan strategis organisasi, kepuasan konsumen, dan memberikan kontribusi pada ekonomi (Armstrong, dan Baron, 1998:15). Dengan demikian, kinerja adalah tentang melakukan pekerjaan dan hasil yang dicapai dari pekerjaan tersebut. Kinerja adalah tentang apa yang dikerjakan dan bagaimana cara mengerjakannya. Seorang karyawan dikatakan berhasil melaksanakan pekerjaannya atau memiliki kinerja yang baik, apabila hasil kerja yang diperoreh lebih tinggi dari standar kinerja. Penilaian kinerja dapat dilakukan dengan membandingkan hasil kerja yang dicapai karyawan dengan standar pekerjaan. Bila hasil kerja yang diperoleh sampai atau melebihi standar pekerjaan dapat dikatakan kinerja seorang karyawan termasuk pada kategori baik. Demikian sebaliknya, seorang karyawan yang hasil pekerjaannya tidak mencapai standar pekerjaan termasuk pada kinerja yang tidak baik atau berkinerja rendah (Bangun 2012).

\section{Tinjauan Empiris}

Salah satu data pendukung
yang perlu dijadikan bagian
tersendiri adalah penelitian terdahulu
yang relevan dengan permasalahan
dan metode yang sedang dibahas
pada penelitian ini. Berikut
merupakan penelitian terdahulu,
berupa beberapa jurnal yang relevan
dengan penelitian yang dilakukan:
1. Faudin, Sungkawati dan Samiadji,
2015 dengan judul Pengaruh stres
kerja terhadap kinerja perawat
melalui kepuasan kerja (Studi
Pada Perawat Instalasi Rawat Inap
Rumah Sakit Militer Kota
Malang)dengan hasil terdapat
pengaruh signifikan dan positif
stress kerja terhadap kinerja
perawat.
2. Chairizal, Ningsih dan Nuryanti,
2014
Dengan judul Pengaruh stres dan
kepuasan kerja terhadap kinerja
perawat rumah sakit Ibu dan Anak
Eria Bunda Pekan baru dan hasil
secara parsial stres berpengaruh
tersendiri adalah penelitian terdahulu yang relevan dengan permasalahan dan metode yang sedang dibahas pada penelitian ini. Berikut merupakan penelitian terdahulu, berupa beberapa jurnal yang relevan dengan penelitian yang dilakukan:

Faudin, Sungkawati dan Samiadji, kerja terhadap kinerja perawat melalui kepuasan kerja (Studi Pada Perawat Instalasi Rawat Inap Rumah Sakit Militer Kota Malang)dengan hasil terdapat pengaruh signifikan dan positif stress kerja terhadap kinerja perawat

2. Chairizal, Ningsih dan Nuryanti, 2014

Dengan judul Pengaruh stres dan kepuasan kerja terhadap kinerja Eria Bunda Pekan baru dan hasil secara parsial stres berpengaruh 
negatif dan signifikan terhadap kinerja dan kepuasan kerja berpengaruh positif dan signifikan terhadap kinerja perawat.

3. Adnyaswari dan Adnyani, (2017) dengan judul Pengaruh Dukungan Sosial dan Burnout terhadap Kinerja Perawat Rawat Inap RSUP Sanglah

Hasil penelitainnya Dukungan sosial memiliki pengaruh positif terhadap kinerja perawat pada bidang rawat inap RSUP Sanglah Denpasar

4 Dodi Wisdiansyah, 2017 yang berjudul Pengaruh Konflik Peran Ganda dan Stres Kerja Terhadap Kinerja Perawat Wanita Rumah Sakit Umum Kota Tarakan, hasil penelitaian menyatakan Stres kerja berpengaruh positif terhadap kinerja perawat wanita Rumah Sakit Umum daerah Kota Tarakan

\section{$\underline{\text { Hipotesis }}$}

Berdasarkan tinjauan diatas maka hipotesis yang akan diuji dalam penelitian adalah :

\section{Pengaruh Stress Kerja terhadap Kinerja Perawat}

$\begin{aligned} & \text { Stress kerja adalah } \\ & \text { suatu } \\ & \text { kondisi } \\ & \text { menciptakang }\end{aligned}$
ketidakseimbangan fisik dan psikis,
adanya
yang mempengaruhi emosi, proses
berpikir, dan kondisi seorang
keryawan (Rivai, 2008). Kinerja
merupakan hasil pekerjaan
yang mempunyai hubungan kuat
dengan tujuan strategis organisasi,
kepuasan konsumen, dan
memberikan kontribusi pada
ekonomi (Armstrong, dan Baron,

1998:15). Dengan demikian, kinerja adalah tentang melakukan pekerjaan dan hasil yang dicapai dari pekerjaan tersebut. Kinerja adalah tentang apa yang dikerjakan dan bagaimana cara mengerjakannya. Stres kerja mempengaruhi kinerja. Tingkat stres yang mampu dikendalikan membuat karyawan melakukan pekerjaannya dengan lebih baik, karena membuat mereka mampu meningkatkan intensitas kerja, kewaspadaan, dan kemampuan berkreasi, tetapi tingkat stress yang berlebihan membuat kinerja mereka akan mengalami penurunan (Robbins, 2006).

Penelitian Chairizal, Ningsih dan Nuryanti (2014) yang berjudul pengaruh stres dan kepuasan kerja terhadap kinerja perawat rumah sakit Ibu dan Anak Eria Bunda Pekan baru, bahwa Secara parsial stres berpengaruh negatif dan signifikan terhadap kinerja perawat Rumah Sakit Ibu dan Anak Eria Bunda Pekanbaru. Artinya Semakin tinggi stres kerja, maka akan semakin rendah kinerja mereka, begitu juga sebaliknya. Selain itu penelitian Dwi Cahyani (2017) dengan judul pengaruh kepusaan kerja dan stres kerja terhadap kinerja perawat rumah sakit PKU Muhammadiyah Yogyakarta Unit 2 menyatakan bahwa stres kerja berpengaruh negatif dan signifikan terhadap kinerja perawat rumah sakit PKU Muhammadiyah Yogyakarta Unit 2. Berdasarkan teori-teori pendukung yang telah di kembangkan, maka hipotesis yang terbentuk adalah:

\section{H1: Stres kerja berpengaruh negatif terhadap kinerja perawat}




\section{Pengaruh Kepuasan Kerja terhadap Kinerja Perawat}

Kepuasan kerja $\begin{array}{r}\text { (job } \\ \text { harus }\end{array}$
statisfaction) karyawan
diciptakan sebaikbaiknya supaya
moral kerja, dedikasi, kecintaan, dan
kedisiplinan karyawan meningkat.
kepuasan kerja merupakan sikap
emosional yang menyenangkan dan
mencintai pekerjaanya (Hasibuan,
2014). Kepuasan kerja mencerminkan perasaan seseorang terhadap pekerjannya. Ini Nampak dalam sikap positif karyawan terhadap pekerjaan dan segala sesuatu yang dihadapi di lingkungan kerjanya. Dengan perasaan yang positif dan senang berkaitan dengan pekerjaan, karyawan diharapkan bekerja dengan baik untuk mencapai kinerja yang diharapkan. Sebaliknya apabila karyawan tidak memiliki kepuasan kerja, kemungkinan pekerjaan tidak terselesaikan dengan baik tinggi. Hal ini dikarenakan karyawan tidak memiliki perasaan positif berkaitan dengan pekerjaannya (Admaji, 2011). Chairizal, Ningsih dan Nuryanti (2014) melakukan penelitian dengan judul Pengaruh Stres dan Kepuasan Kerja terhadap Kinerja Perawat Rumah Sakit Ibu dan Anak Eria Bunda Pekanbaru. Dari hasil penelitiannya menyatakan bahwa kepuasan kerja berpengaruh positif dan signifikan terhadap kinerja perawat Rumah Sakit Ibu dan Anak Eria Bunda Pekanbaru. Artinya semakin tinggi kepuasan kerja, maka kinerja juga akan meningkat dan begitu pula sebaliknya ketika kepuasan kerja menurun maka kinerja juga akan menurun. Selain itu penelitian Dwi Cahyani (2017) dengan judul pengaruh kepusaan kerja dan stres kerja terhadap kinerja perawat rumah sakit PKU Muhammadiyah Yogyakarta Unit 2 menyatakan bahwa kepuasan kerja berpengaruh positif dan signifikan terhadap kinerja perawat rumah sakit PKU Muhammadiyah Yogyakarta Unit 2. Berdasarkan teori-teori pendukung yang telah di kembangkan, maka hipotesis yang terbentuk adalah:

H2: Kepuasan Kerja Berpengaruh Positif terhadap Kinerja Perawat

\section{Pengaruh Dukungan Sosial terhadap Kinerja Perawat}

Menurut Rahim (2006), dukungan sosial didefinisikan sebagai ketersediaan bantuan baik itu yang berasal dari supervisor, rekan kerja, anggota keluarga, dan teman. Menurut Cobb dukungan sosial digambarkan sebagai pengalaman yang memberikan keyakinan pada seseorang bahwa dirinya dicintai, diperhatikan. Dukungan sosial mempengaruhi kinerja. Kinerja merupakan hasil pekerjaan yang mempunyai hubungan kuat dengan tujuan strategis organisasi, kepuasan konsumen, dan memberikan kontribusi pada ekonomi (Armstrong, dan Baron, 1998:15). Dengan demikian, kinerja adalah tentang melakukan pekerjaan dan hasil yang dicapai dari pekerjaan tersebut. Kinerja adalah tentang apa yang dikerjakan dan bagaimana cara mengerjakannya. Dukungan sosial yang tinggi akan meningkatkan kinerja perawat. Ketika Suasana kerja yang baik tercipta antara lain karena adanya dukungan sosial di 
lingkungan individu, sehingga dapat meningkatkan semangat kerja dan mennghasilkan kinerja yang baik

Penelitian yang dilakukan Adnyaswari dan Adnyani, (2017) pengaruh dukungan sosial dan bornout terhadap kinerja perawat rawat inap RSUP Sanglah, menyatakan bahwa dukungan sosial memiliki pengaruh positif terhadap kinerja perawat pada bidang rawat inap RSUP Sanglah. Ini artinya bahwa ketika dukungan sosial perawat tinggi, akan meningkatkan kinerja, dan sebaliknya ketika dukungan sosial rendah akan menurunkan kinerja. Selain itu penelitian Avira Rizqiana Yulia (2017) dengan judul pengaruh pekerjaan keluarga dan dukungan sosial serta kecerdasan emosional terhadap stres dan kinerja perawat wanita di RSD dr. soebandi Jember menyatakan bahwa Dukungan sosial berpengaruh signifikan dan positif terhadap kinerja perawat wanita RSD dr. Soebandi Jember. Dapat dijelaskan bahwa dukungan sosial yang diterima perawat tersebut tinggi maka mampu meningkatkan kinerja perawat wanita RSD dr. Soebandi Jember. Begitu pula sebaliknya, bahwa jika dukungan sosial rendah, maka kinerja akan menurun. Berdasarkan teori-teori pendukung yang telah di kembangkan, maka hipotesis yang terbentuk adalah

H3: Dukungan sosial Berpengaruh positif terhadap kinerja Perawat

\section{Kerangka Penelitian}

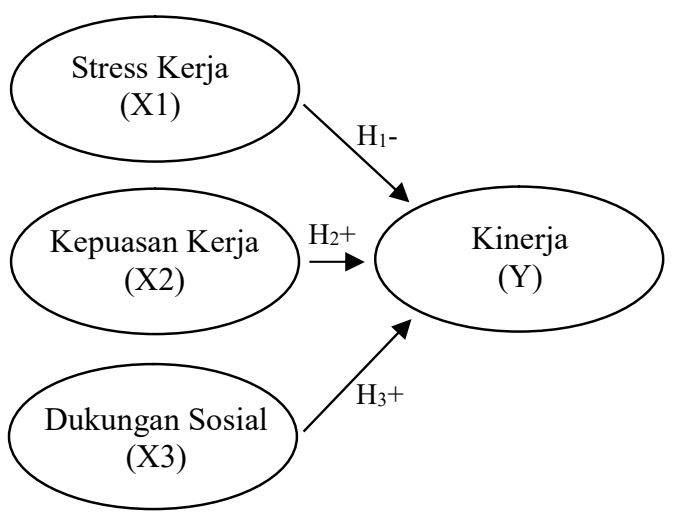

\section{METODOLOGI PENELITIAN}

Penelitian ini menggunakan pendekatan kuantitatif dengan metode survey dalam bentuk kuesioner. Populasi dalam penelitian ini adalah Perawat puskesmas Aji kuning dan Puskesmas Sungai Nyamuk . Dalam penelitian ini, peneliti mengambil sampel dengan menggunakan teknik non probability sampling yaitu sampling jenuh. jumlah populasi yaitu 36 perawat puskesmas Aji Kuning dan Puskesmas Sungai Nyamuk.

Metode analisis data yang digunakan dalam penelitian ini terdiri dari Uji Validitas, Uji Reliabilitas dan analisis regresi berganda. Berikut diuraikan metode analisis data dalam penelitian ini.

Uji Validitas Berdasarkan hasil uji validitas variabel Stres Kerja, kepuasan kerja, dukungan sosial dan kinerja terhadap masing-masing indikator variabel menunjukkan bahwa terdapat nilai korelasi yang dipersyaratkan yaitu sebesar 0,3291 dan semua item variabel bebas maupun terikat memiliki nilai yang 
lebih besar dari nilai yang di persyaratkan yakni $>0,3291$ sehingga semua item dikatakan valid dan dapat diproses dalam pengujian selanjutnya.

Uji Reliabilitas Berdasarkan hasil uji reliabilitas pada variabel stres kerja, kepuasan kerja, dukungan sosial dan kinerja menunjukkan bahwa nilai Cronbach's Alpha semua item variabel bebas maupun variabel terikat $>0,60$, maka item dalam semua variabel adalah reliabel. Maka dapat diartikan instrumen pada variabel Stres Kerja, Kepuasan kerja, dukungan sosial dan kinerja memiliki kestabilan dan konsisten responden dalam menjawab hal yang berkaitan dengan pernyataan yang merupakan dimensi suatu variabel yang disusun dalam suatu bentuk kuesioner

Analisis Regresi Berganda Analisis ini digunakan untuk mengetahui seberapa besar pengaruh variabel bebas yaitu: stres kerja (X1), Kepuasan kerja (X2)dan Dukungan sosial (X3)terhadap variabel terikatnya yaitu kinerja karyawan (Y). Berikut adalah tabel analisis regresi berganda:

\begin{tabular}{|l|l|l|l|l|}
\hline $\begin{array}{l}\text { Hubunga } \\
\mathrm{n}\end{array}$ & Beta & $\begin{array}{l}\text { thitun } \\
\mathrm{g}\end{array}$ & ttabel & Ket \\
\hline $\begin{array}{l}\text { Stres } \\
\text { Kerja } \\
\text { terhadap } \\
\text { Kinerja }\end{array}$ & 0,16 & 2,991 & $\begin{array}{l}1.6938 \\
9\end{array}$ & $\begin{array}{c}\text { HI } \\
\text { diterim } \\
\mathrm{a}\end{array}$ \\
\hline $\begin{array}{l}\text { Kepuasan } \\
\text { kerja } \\
\text { terhadap } \\
\text { Kinerja }\end{array}$ & 0,16 & 1.390 & 1.6938 & $\begin{array}{l}\mathrm{H} 2 \\
\text { ditolak }\end{array}$ \\
\hline $\begin{array}{l}\text { Dukunga } \\
\text { n Sosial } \\
\text { terhadap } \\
\text { Kinerja }\end{array}$ & 0,33 & 1,992 & 1.6938 & $\begin{array}{c}\text { H3 } \\
\text { diterim } \\
\text { a }\end{array}$ \\
\hline \multicolumn{5}{|c|}{ Sumber :Output SPSS diolah, 2019 } \\
\hline
\end{tabular}

Kerja terhadap Kinerja menunjukkan bahwa nilai thitung sebesar 2,991, ttabel sebesar 1,69389 dan nilai signifikan sebesar 0,005 , maka dapat di simpulkan bahwa thitung $>$ ttabel dan nilai signifikan lebih kecil dari 0,05. Hal tersebut menunjukkan bahwa stres kerja berpengaruh negatif dan signifikan terhadap kinerja. Dengan demikian dapat di simpulkan bahwa hipotesis 1 diterim

Hasil pengujian statistik Kepuasan Kerja terhadap Kinerja menunjukkan bahwa nilai thitung sebesar 1,390, ttabel sebesar 1,69389 dan nilai signifikan sebesar 0,174 , maka dapat di simpulkan bahwa thitung $<$ ttabel dan nilai signifikan lebih besar dari 0,05. Hal tersebut menunjukkan bahwa kepuasan kerja tidak ada pengaruh yang signifikan terhadap kinerja. Dengan demikian dapat di simpulkan bahwa hipotesis 2 ditolak.

Hasil pengujian statistik Dukungan Sosial terhadap Kinerja menunjukkan bahwa nilai thitung sebesar 1,992 ttabel sebesar 1,69389 dan nilai signifikan sebesar 0,055 , maka dapat di simpulkan bahwa thitung $>$ ttabel dan nilai signifikan lebih besar dari 0,05. Hal tersebut menunjukkan bahwa dukungan sosial berpengaruh positif dan signifikan terhadap kinerja. Dengan demikian dapat di simpulkan bahwa hipotesis 3 diterima

\section{PEMBAHASAN}

\section{Pembahasan Stres Kerja terhadap Kinerja Perawat Puskesmas Sebatik.}

Berdasarkan hasil penelitian ini yang dilakukan pada perawat Puskesmas Sungai Nyamuk dan 
Puskesmas Aji Kuning menunjukkan bahwa stres kerja

berpengaruh negatif dan signifikan terhadap kinerja perawat. Hal ini dilihat dari thitung $>$ ttabel dan nilai signifikannya lebih kecil dari 0,05 . Artinya semakin tinggi stres kerja pada perawat maka akan menurunkan kinerja perawat, begitupun sebaliknya ketika stres kerja sedang atau dapat di atasi maka dapat meningkatkan kinerja perawat. Dalam penelitian ini adapun indikator yang paling banyak di setujui responden yaitu mereka merasa kecewa bila tidak dapat menyelesaikan pekerjaannya tepat waktu dan semangat kerjanya menurun ketika pekerjaan yang mereka kerjakan tidak di hargai sehingga membuat mereka stres sehingga kinerja perawat akan menurun. Selain itu perawat memiliki beban kerja yang tinggi, harus siap melayani pasien dengan keluhan dan penyakit yang berbedabeda dan berhubungan dengan nyawa pasien. Perawat yang merasa stres dapat berdampak pada kesehatan mereka, sehingga ketika perawat mengalami gangguan kesehatan maka mereka tidak dapat berkonsentrasi dalam menjalankan tugasnya dan dapat menurunkan kinerja perawat.

\section{Pembahasan Kepuasan Kerja terhadap Kinerja Perawat Puskesmas Sebatik.}

Berdasarkan hasil penelitian ini yang dilakukan pada perawat Puskesmas Sungai Nyamuk dan Puskesmas Aji Kuning menunjukkan bahwa kepuasan kerja tidak ada berpengaruh yang signifikan terhadap kinerja perawat. Hal ini dilihat dari thitung $<$ ttabel dan nilai signifikannya lebih besar dari 0,05 . Artinya ketika kepuasan kerja perawat tinggi atau kepuasan kerja perawat rendah tidak mempengaruhi kinerja perawat. Dari hasil data responden, Perawat di puskesmas Sungai Nyamuk dan puskesmas Aji kuning tidak puas dengan gaji yang di terima karena tidak dapat memenuhi kebutuhannya, akan tetapi walaupun perawat puskesmas Aji Kuning dan Sungai Nyamuk tidak puas dengan gaji yang mereka terima, tidak berpengaruh dengan Kinerjanya. Hal ini di buktikan dengan hasil data responden yang menyatakan bahwa mereka mampu menyelesaikan pekerjaannya sesuai standar puskesmas, dapat menyelesaikan pekerjaannya secara cepat dan efisien serta bersungguhsungguh menjalankan tugas dan tanggung jawab yang diberikan oleh atasannya.

Selain itu faktor yang menyebabkan kepuasan kerja tidak berpengaruh terhadap kinerja perawat adalah tugas dan tanggung jawab perawat, karena tugas dan tanggung jawab perawat tidak sama dengan tugas dan tanggung jawab karyawan yang bekerja di perusahaan lain. Tugas perawat yakni pada bidang pelayanan sosial yang selalu bersikap sabar dan dapat memahami keadaan pasien yang sedang mengalami kesakitan, ketakutan, krisis serta mengurus semua kebutuhan pasien di puskesmas dan itu berhubungan dengan nyawa seseorang. Jadi kepuasan kerja pada perawat tidak berpengaruh terhadap kinerja 


\section{Pembahasan Dukungan Sosial terhadap Kinerja Perawat Puskesmas Sebatik.}

Berdasarkan hasil penelitian yang dilakukan pada perawat Puskesmas Sungai Nyamuk dan Puskesmas Aji Kuning menunjukkan bahwa dukungan sosial berpengaruh positif dan tidak signifikan terhadap kinerja perawat. Hal ini dilihat dari thitung $>$ ttabel dan nilai signifikannya lebih besar dari 0,05 . Artinya semakin tinggi dukungan sosial yang diberikan maka kinerja perawat akan semakin meningkat begitu pun sebaliknya ketika dukungan sosial rendah maka kinerja perawat akan menurun. Dalam penelitian ini adapun indikator dukungan sosial yang paling banyak di setujui yaitu "keluarga saya mendukung pekerjaan saya", artinya dukungan yang paling banyak di terima perawat yaitu dukungan sosial dari keluarganya. Dukungan sosial adalah dukungan yang diberikan dari orang-orang sekitar dalam bentuk perhatian, penghargaan, motivasi dan bantuan langsung, maupun tidak langsung. Dukungan sosial meliputi, dukungan keluarga, teman dan atasan. Ketika perawat mendapatkan dukungan sosial dari keluarga, teman ataupun atasan, baik dalam bentuk perhatian, penghargaan, bantuan langsung, atau tidak langsung maka dapat meningkatkan kepercayaan terhadap diri sendiri, sehingga kinerja perawat akan meningkat.

\section{KESIMPULAN}

Penelitian ini bertujuan unutk mengetahui pengaruh Stres Kerja, kepuasan Kerja dan Dukungan Sosial terhadap Kinerja Perawat Puskesmas
Sebatik. Responden dalam penelitian ini berjumlah 36 Perawat Puskesmas Sungai dan Puskesmas Aji Kuning. Setelah peneliti melakukan analisis dalam bab-bab sebelumnya maka peneliti dapat memberikan beberapa kesimpulan, yaitu: Terdapat pengaruh negatif dan signifikan antara Stres kerja terhadap Kinerja perawat di puskesmas Sungai Nyamuk dan Aji Kuning, Tidak terdapat pengaruh yang signifikan antara Kepuasan Kerja terhadap kinerja perawat di puskesmas Sungai Nyamuk dan Aji Kuning, serta Dukungan Sosial berpengaruh positif dan tidak signifikan terhadap kinerja perawat di puskesmas Sungai Nyamuk dan Aji Kuning.

\section{Saran}

Berdasarkan pembahasan yang telah di uraikan, maka saran yang dapat diberikan oleh peneliti yaitu :

1 Bagi pimpinan puskesmas sebaiknya memperhatikan kinerja karyawannya, untuk memperoleh kinerja yang baik, perlu ada kepuasan kerja, karena dengan adanya kepuasan kerja yang tinggi dapat meningkatkan kinerja perawat. Misalnya memberikan balas jasa yang adil dan layak untuk karyawannya, yakni memberikan gaji yang sesuai dengan hasil kerjanya dan memberikan peluang yang sama untuk promosi jabatan terhadap karyawan yang memiliki prestasi kerja sehingga karyawan merasa puas dengan hasil kerjanya.

2 Bagi peneliti selanjutnya dapat mengembangkan penelitian ini dengan meneliti faktor-faktor 
yang dapat mempengaruhi kinerja Peneliti selanjutnya dapat mengambil jumlah sampel yang lebih besar dari pada sampel yang ada dalam penelitian ini sehingga penelitian selanjutnya akan lebih valid.

\section{DAFTAR PUSTAKA}

Admanji, Luthfan. 2011. Pengaruh Stres Kerja Dan Kepuasan Kerja terhadap Kinerja Perawat. Skripsi. Semarang:Universitas Diponegoro.

Akil, Yansyah Hari. 2016. Pengaruh Etika Kerja, Konflik Kerja dan Dukungan terhadap Kinerja Karyawan Hotel Nusantara Bandar Lampung. Skripsi. Universitas Lampung: Bandar Lampung.

Adnyaswari, Nyoman Adinda dkk. 2017. Pengaruh Dukungan Sosial dan Burnout terhadap Kinerja Perawat Rawat Inap Rsup Sanglah. E-Jurnal Manajemen Unud, Vol. 6, No. 5.

Bangun, Wilson. 2012. Manajemen Sumber Daya Manusia. Jakarta: Erlangga

Chairizal, Novianto Tedy dkk. 2014. Pengaruh Stres dan Kepuasan Kerja terhadap Kinerja Perawat Rumah Sakit Ibu dan Anak Eria Bunda Pekanbaru. Jom Fekon. Vol.1 No.2.

Cahyani, Dwi. 2017. Pengaruh Kepuasan Kerja dan Stres Kerja terhadap Kinerja Perawat Rumah Sakit PKU Muhammadiyah Yogyakarta Unit 2. Skripsi. Yogyakarta. Universitas Negeri Yogyakarta.

Faudin, Mokhamad Afif. 2015. Pengaruh Stres kerja terhadap kinerja perawat melalui kepuasan kerja (Studi Kasus pada Perawat Instalasi Rawat Inap Rumah Sakit Meliter Kota Malang). Jurnal Manajemen.

Gaffar, Hulaifah. 2012. Pengaruh stres kerja terhadap kinerja karyawan pada PT. Mandiri (persero) Tbk kantor wilayah x Makassar. Skripsi. Makassar: Univeritas Hasanuddin Makassar. Hasibuan, Malayu. 2009. Manajemen Sumber Daya Manusia. Jakarta: PT Bumi Aksara.

Hasibuan, Malayu. 2014. Manajemen Sumber Daya Manusia. (edisi revisi). Jakarta: PT Bumi Aksara.

Kristine, Erline. 2017. Pengaruh Kepuasan Kerja dan Komitmen Organisasi terhadap Kinerja melalui Motivasi Kerja Pegawai Alih Daya (Outsourcing) di PT. Mitra Karya Jaya Santosa. Jurnal Eksekutif, Vol. 14.

Marchelia, Venny. 2014. Stres Kerja ditinjau dari Shift Kerja pada Karyawan. Jurnal Ilmiah Psikologo Terapan, Vol.02, No.01.

Masbow. 2009. Apa Itu Dukungan Sosial?. Artikel, http://www.masbow.com. (diakses 25 Desember 2018)

Suryaningrum, Tri. 2015.

Pengaruh Beban Kerja dan Dukungan Sosial Terhadap Stres kerja pada Perawat RS PKU Muhammadiyah Yogyakarta. Skripsi. Yogyakarta: Universitas Negeri Yogyakarta.

Wirawan. 2009. Evaluasi Kinerja Sumber Daya Manusia. Jakarta: Salemba Empat

Yulia, Avira Rizqiana. 2017. Pengaruh Pekerjaan Keluarga dan Dukungan Sosial serta Kecerdasan Emosional terhadap Stres dan 
Kinerja Perawat Wanita di RSD dr. Soebandi Jember. Jurnal Bisnis dan Manajemen, Vol.11, No.1.

Kazemian A, Nooriyan K, Parvin K. 2005. Survey the relationship between job satisfaction and job performance of nurses in ChaharMahal Bakhtiari. Journal of nursing and midwifery of gilan.

Siagian, Sondang. 2018. Manajemen Sumber Daya Manusia. (Edisi 1, Cetakan 26). Jakarta: PT Bumi Aksara. 
